\title{
MODEL PENILAIAN KONTRAKTOR PADA PROYEK KETENAGALISTRIKAN MENGGUNAKAN METODE AHP DAN FUZZY TOPSIS
}

\author{
Dodi Angga Kusuma \\ Magister Manajemen Teknologi ITS, Surabaya \\ dodiangga24@gmail.com \\ Bambang Syairudin \\ Magister Manajemen Teknologi ITS, Surabaya \\ bambangsy@yahoo.com \\ Fuad Achmadi \\ Magister Manajemen Teknologi ITS, Surabaya \\ fuadachmadi@yahoo.co.id
}

\begin{abstract}
The objective of this study is to analyze the contractor assessment model for the electricity project. This study focused on the procurement process of goods/services for the construction of a $500 \mathrm{kV}$ Duri Kosambi Gas Insulated Switchgear Tegangan Ekstra Tinggi (GISTET). The sample consisted of 2 (two) contractors, i.e., PT CA and PT PCE. Data were analyzed using AHP (Analytical Hierarchy Process) and Fuzzy TOPSIS (Technique for Order Preference by Similarity to Ideal Solution) models. Referring to AHP and Fuzzy TOPSIS models, the selection of project contractor was based on 3 (three) main criteria: administration, technical, price, and 10 (ten) sub criteria: financial qualification documents, documents from the bank, list of jobs in the implementation, TKDN, manufacturer's production experience, customer satisfaction certificates, technical specifications, brochure and TPG, price quotes, and fairness of offers. The results of the assessment showed that PT CA with the value of 0.723 was the best contractor for the project.
\end{abstract}

Keywords: Procurement, Electricity Project, AHP, and Fuzzy TOPSIS.

\begin{abstract}
Abstrak: Tujuan dari penelitian ini adalah untuk menganalisis model penilaian kontraktor pada proyek ketenagalistrikan. Fokus penelitian adalah pada pemilihan penyedia barang/jasa untuk pembangunan Gas Insulated Switchgear Tegangan Ekstra Tinggi (GISTET) 500 kV Duri Kosambi. Metode analisis yang digunakan adalah metode AHP (Analytical Hierarcy Process), dan Fuzzy TOPSIS. Pemilihan kontraktor proyek dengan model AHP dan Fuzzy TOPSIS menggunakan 3 (tiga) kriteria utama, yaitu: administrasi, teknis, dan harga, serta 10 (sepuluh) sub kriteria, yaitu: dokumen kualifikasi keuangan, dokumen dari bank, daftar pekerjaan dalam pelaksanaan, dokumen kualifikasi finansial, TKDN, pengalaman produksi pabrikan, surat keterangan kepuasan pelanggan, spesifikasi teknis, brochure dan TPG, penawaran harga, dan kewajaran penawaran. Hasil penilaian yang dilakukan menunjukan bahwa PT CA dengan nilai 0,723 merupakan kontraktor terbaik.
\end{abstract}

Kata Kunci: Pengadaan Barang dan Jasa, Proyek Ketenagalistrikan, AHP, dan Fuzzy TOPSIS

\section{Pendahuluan}

Pengadaan barang/jasa menduduki posisi yang sangat penting dalam suatu organisasi, karena merupakan sarana penggunaan anggaran dalam jumlah signifikan guna mendapatkan barang, jasa, dan pekerjaan yang dibutuhkan bagi pelaksanaan 
misi organisasi. Pengadaan barang/jasa juga menduduki posisi penting dalam Penyediaan infrastruktur ketenagalistrikan yang dilakukan oleh PT PLN (Persero), selanjutnya disebut PLN. Pengadaan barang/jasa adalah kegiatan pengadaan barang, pengadaan jasa konstruksi termasuk pengadaan barang dan pemasangan (supply \& erect), pengadaan jasa konstruksi, pengadaan khusus dan pengadaan jasa lainnya di PLN yang dibiayai dengan APLN atau yang dibiayai dengan sumber dana pinjaman/hibah luar negeri dan/atau pinjaman dalam negeri (Non APLN), sepanjang tidak diatur dalam naskah pemberi pinjaman (guide lines).

Sebagai sebuah perusahaan listrik milik negara yang merencanakan dan melaksanakan proyek-proyek kelistrikan. PLN berkewajiban menyediakan tenaga listrik dalam jumlah yang cukup kepada masyarakat di seluruh Indonesia secara terus menerus, baik dalam jangka pendek maupun jangka panjang. PLN pada prinsipnya bermaksud melayani kebutuhan tenaga listrik seluruh masyarakat di wilayah Indonesia. Dalam pelaksanaannya, beberapa proyek mengalami kendala di lapangan yang diakibatkan antara lain kendala pembebasan lahan, relokasi, Rencana Tata Ruang Wilayah (RTRW) dan kemampuan kontraktor yang menyebabkan belum terselesaikannya pembangunan infrastruktur ketenagalistrikan sesuai yang direncanakan.

Pengembangan saluran transmisi dan Gl secara umum diarahkan kepada tercapainya keseimbangan antara kapasitas pembangkitan di sisi hulu dan permintaan daya di sisi hilir secara efisien dengan memenuhi kriteria keandalan tertentu. Rencana pengembangan sistem penyaluran di Indonesia hingga tahun 2025 diproyeksikan sebesar 164,7 MVA untuk pengembangan gardu induk dengan perincian pada Tabel 1. Dari tabel tersebut terlihat bahwa ada penambahan fasilitas yang sangat besar pada tahun 2016 - 2019, hal ini karena adanya keterlambatan penyelesaian proyek yang seharusnya beroperasi sebelum tahun 2016.

Tabel 1. Kebutuhan Fasilitas Trafo dan Gardu Induk Indonesia

\begin{tabular}{|c|c|c|c|c|c|c|c|c|c|c|c|}
\hline TRAFO & 2016 & 2017 & 2018 & 2019 & 2020 & 2021 & 2022 & 2023 & 2024 & 2025 & Total \\
\hline $500 / 275 \mathrm{kV}$ & - & - & 1,500 & 1,000 & 500 & - & 750 & - & - & - & 3,750 \\
\hline $500 / 150 \mathrm{kV}$ & 4,838 & 8,668 & 9,500 & 5,000 & 4,000 & - & - & 1,000 & - & 5,500 & 38,506 \\
\hline $500 \mathrm{kV} \mathrm{DC}$ & - & - & - & 6,000 & 600 & - & - & - & - & - & 6,600 \\
\hline $275 / 150 \mathrm{kV}$ & 5,750 & 3,680 & 2,000 & 4,500 & - & 700 & 1,000 & 250 & 520 & 1,250 & 19,650 \\
\hline $150 / 70 \mathrm{kV}$ & 90 & 1,290 & 100 & 60 & 60 & - & - & - & - & - & 1,600 \\
\hline $150 / 20 \mathrm{kV}$ & 12,870 & 21,280 & 11,260 & 12,160 & 6,520 & 6,320 & 6,370 & 8,560 & 6,560 & 7,390 & 99,290 \\
\hline $70 / 20 \mathrm{kV}$ & 730 & 770 & 440 & 180 & 170 & 60 & 120 & 150 & 30 & 90 & 2,740 \\
\hline TOTAL & 24,278 & 35,688 & 24,800 & 28,900 & 11,850 & 7,080 & 8,240 & 9,960 & 7,110 & 14,230 & 172,136 \\
\hline
\end{tabular}


Penelitian ini memfokuskan studi pada pemilihan penyedia barang/jasa untuk pembangunan Gas Insulated Switchgear Tegangan Ekstra Tinggi (GISTET) 500 kV Duri Kosambi. GISTET 500 kV Duri Kosambi ini merupakan bagian dari pembangunan 7 GITET yang akan memperkuat sistem kelistrikan Jakarta dan sekitarnya, yaitu GITET Kembangan, GITET Lengkong, GITET Muara Karang, GITET Priok, GITET Muara Tawar, dan GITET Tambun yang dikenal dengan nama Proyek Jaringan 500 kV Looping Jakarta. Beban puncak sistem kelistrikan di provinsi DKI Jakarta (tidak termasuk Kepulauan Seribu) diperkirakan sampai Agustus 2015 sekitar 4.615 MW. Pasokan pembangkit yang terhubung di grid $150 \mathrm{kV}$ adalah sekitar 3.690 MW yang berada di 2 lokasi yaitu PLTGU/PLTU Muara Karang dan PLTGU/PLTG Tanjung Priok.

Keputusan memilih penyedia barang/jasa harus didukung oleh pertimbangan yang objektif dan menguntungkan dalam pencapaian waktu, biaya dan kualitas. Menurut, sebagian besar evaluasi pemilihan kontraktor pemenang tender untuk proyek-proyek pemerintah (public works) maupun proyek-proyek swasta (private works) hanya ditentukan oleh satu kriteria yaitu harga terendah (lowest bid). Sementara para peneliti menemukan bahwa dalam pemilihan kontraktor berdasarkan harga terendah sering menimbulkan banyak masalah dari sisi pemerintah yaitu kualitas proyek yang buruk dan biaya maintenance yang membengkak (Liauwnoto, 2009). Selain itu, pemilihan kontraktor dengan harga terendah belum tentu ekonomis untuk solusi jangka panjang.

Pengambilan keputusan pada saat melakukan pemilihan kontraktor bukanlah hal yang mudah, maka diperlukan suatu model pengambilan keputusan untuk membantu memecahkan masalah tersebut. AHP (Analytical Hierarchy Process) merupakan salah satu metode MCDM (Multi Criteria Decision Making) yang sangat baik dalam memodelkan pendapat para ahli dalam sistem pendukung keputusan. Dalam menyusun model, AHP melakukan perbandingan berpasangan variabelvariabel yang menjadi penentu dalam proses pengambilan keputusan (Calabrese et al., 2013). Namun metode AHP tidak efektif digunakan pada kasus yang dengan jumlah kriteria dan alternatif yang banyak (Rouhani et al., 2012), untuk menutupi kelemahan itu, diperlukan satu metode pengambilan keputusan lainnya, yaitu TOPSIS (Technique for Order Performance by Similarity to Ideal Solution). Salah satu masalah dari metode TOPSIS (Technique for Order Performance by Similarity to Ideal Solution) adalah penggunaan nilai kuantitatif dalam proses evaluasi. Kesulitan lain 
untuk menggunakan nilai kuantitatif adalah bahwa beberapa kriteria yang sulit diukur oleh nilai-nilai kuantitatif, sehingga selama evaluasi kriteria ini biasanya diabaikan. Penggunaan teori himpunan fuzzy memungkinkan para pengambil keputusan untuk menggunakan informasi kualitatif dan informasi yang tidak lengkap. Fuzzy TOPSIS (Technique for Order Performance by Similarity to Ideal Solution) digunakan karena kemudahan menggunakan bilangan fuzzy untuk menghitung pengambil keputusan. Selain itu, telah diverifikasi bahwa pemodelan dengan bilangan fuzzy adalah cara yang efektif untuk merumuskan masalah, dimana informasi yang tersedia bersifat subyektif dan tidak akurat (Rouhani et al., 2012).

Metode AHP (Analytical Hierarchy Process) adalah metode yang sederhana dan mampu memecahkan masalah dengan multi kriteria, yang dapat digunakan dalam pengambilan keputusan pemilihan kontraktor. Hasil yang diperoleh dari Analytical Hierarchy Process selanjutnya akan diolah dengan menggunakan Fuzzy TOPSIS untuk memperoleh alternatif yang paling dekat dengan solusi ideal. Dengan menggunakan metode AHP dan diperkuat dengan metode Fuzzy TOPSIS dapat menyeleksi dan mengevaluasi kontraktor sehingga dapat menentukan kriteria dan alternative kontraktor yang tepat.

\section{Metodologi}

Data yang dikumpulkan dalam penelitian ini adalah semua data yang diperlukan untuk model penilain kontraktor, mulai dari penentuan kriteria, sub kriteria, comparison judgement, penilaian kontraktor. Tahap-tahap pengolahan data dengan metode Delphi, AHP dan fuzzy TOPSIS secara rinci adalah sebagai berikut:

\section{Tahap Penentuan Kriteria}

Menentukan kriteria dan sub kriteria Peneliti melalui metode Delphi dengan naras sumber yang berkaitan dengan kontrak konstruksi yaitu mewakili masingmasing bidang. Sebelum mulai dilakukan perhitungan dengan metode AHP terlebih dahulu dibuat struktur hirarki AHP untuk Pemilihan Kontraktor yang ditampilkan pada Gambar 2. berikut : 


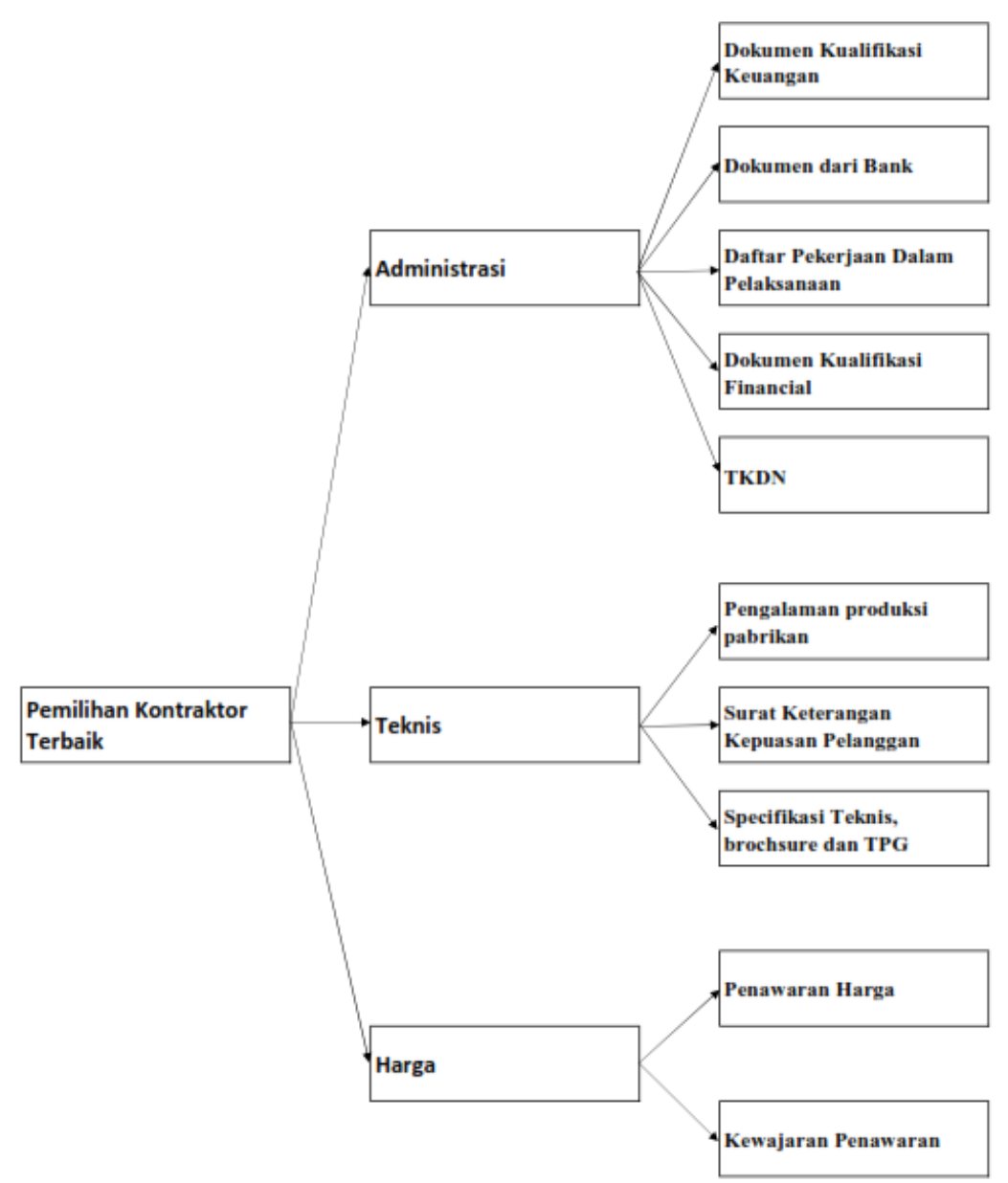

Gambar 1. Hirarki Pembobotan Pemilihan Kontraktor (AHP)

\section{Tahap Penyusunan Kuesioner}

Setelah menentukan kriteria dan sub kriteria untuk bahan pertimbangan pemilihan kontraktor yang terbaik, disusunlah kuesioner penelitian. Penyusunan kuesioner dibuat berdasarkan metode perbandingan berpasangan untuk mengetahui tingkat bobot dari setiap kriteria dan sub kriteria. Nilai bobot tersebut mulai dari angka 1 hingga 9 yang disesuaikan dengan tingkat kepentingan sub kriteria. Kuesioner tersebut berisi perbandingan antara tiap kriteria dengan kriteria lainnya, dan perbandingan antara tiap sub kriteria dengan sub kriteria lainnya (Tantyonimpuno \& Retnaningtias, 2006: 35)

\section{Tahap Pengolahan Data}

Metode analisa data yang digunakan menggunakan metode AHP (dan Fuzzy TOPSIS. Metode Delphi digunakan pada saat pengambilan keputusan dari sisi pemilik proyek untuk menentukan kriteria dan sub kriteria. Sedangkan metode AHP (digunakan pada saat melakukan pembobotan. Fuzzy TOPSIS digunakan pada saat pengambilan keputusan sesuai dengan hasil kriteria yang telah ditetapkan 
perusahaan dari hasil pemilihan kriteria pada tahap sebelumnya. Proses penilaian kontraktor dengan menggunakan metode AHP dan Fuzzy TOPSIS karena dengan metode AHP dan Fuzzy TOPSIS diharapkan kriteria dan pembobotan dari kriteria terpilih terdeteksi dengan baik, sehingga didapatkan hasil kontraktor terbaik dan dapat menjadi pertimbangan untuk digunakan di proyek selanjutnya.

\section{Hasil dan Pembahasan}

Analisa hasil merupakan proses analisa penelitian dari hasil survei yang dilakukan peneliti terhadap objek penelitian. Dalam penelitian ini, proses analisa dilakukan dengan 3 tahap yaitu dengan mencari kriteria dan faktor yang paling mempengaruhi proses penilaian dalam suatu proyek konstruksi dari sisi value for money comitte yang mengetahui tujuan serta visi misi perusahaan dengan menggunakan Metode Delphi. Tahap analisa kedua dengan menggunakan metode AHP, metode AHP sebagai salah satu alat penentuan pembobotan kriteria. Tahap analisa ketiga dengan menggunakan fuzzy TOPSIS sebagai proses perangkingan evaluasi alternatif kontraktor terbaik.

\section{Tahap Penentuan Kriteria (Metode Delphi)}

Pada tahap seleksi kontraktor ini digunakan Metode Delphi sebagai metode analisa untuk menentukan faktor yang paling berpengaruh dalam suatu proyek konstruksi dilihat dari kacamata value for money committee (Watt, Kayis and Willey, 2010). Proses analisa dimulai dari penyebaran kuisioner, dalam kuisioner dijelasakan maksud dan tujuan peneliti serta responden diharapakan mengisi pertanyaan yang diajukan yaitu kriteria apa sajakah yang menjadi pertimbangan pemilihan kontraktor dalam suatu proyek konstruksi. Peneliti juga memberikan asumsi kriteria berdasarkan data dari studi literatur. 
Tabel 2. Kriteria dan Sub Kriteria

\begin{tabular}{|c|l|c|c|c|c|c|c|c|c|}
\hline No & \multicolumn{1}{|c|}{ Sub Kriteria } & RS & BW & UA & NY & OA & Total & Nilai & \% \\
\hline \hline 1 & $\begin{array}{l}\text { Specifikasi Teknis, } \\
\text { brochsure dan TPG }\end{array}$ & 9 & 9 & 9 & 9 & 8 & 44.00 & 8.80 & 3.49 \\
\hline 2 & $\begin{array}{l}\text { Surat Keterangan Kepuasan } \\
\text { Pelanggan / satisfactory letter }\end{array}$ & 9 & 9 & 9 & 8 & 8 & 43 & 8.60 & 3.42 \\
\hline 3 & $\begin{array}{l}\text { Dokumen Kualifikasi } \\
\text { Keuangan }\end{array}$ & 8 & 8 & 8 & 9 & 9 & 42 & 8.40 & 3.34 \\
\hline 4 & $\begin{array}{l}\text { Dokumen Kualifikasi } \\
\text { Financial }\end{array}$ & 9 & 8 & 8 & 8 & 9 & 42 & 8.40 & 3.34 \\
\hline 5 & TKDN & 9 & 8 & 8 & 8 & 8 & 41 & 8.20 & 3.26 \\
\hline 7 & $\begin{array}{l}\text { Pengalaman produksi } \\
\text { pabrikan }\end{array}$ & 8 & 8 & 8 & 8 & 8 & 40 & 8.00 & 3.18 \\
\hline 9 & $\begin{array}{l}\text { Daftar Pekerjaan Dalam } \\
\text { Pelaksanaan dan fotokopi }\end{array}$ & 8 & 9 & 8 & 7 & 7 & 39 & 7.80 & 3.10 \\
\hline 10 & Penawaran Harga & 8 & 7 & 7 & 8 & 8 & 38 & 7.60 & 3.02 \\
\hline
\end{tabular}

Sumber: data diolah, 2017

Dari hasil analisa survei yang dilakukan kriteria yang digunakan yaitu pada 10 (sepuluh) kriteria teratas karena berdasarkan hasil survei tahap 1 (satu) kriteria tersebut bukan merupakan prioritas value for money comitte dalam proses penilaian kontraktor.

\section{Pembobotan Kriteria (AHP)}

Berdasarkan hasil pengumpulan dan pengolahan data dengan metode Delphi didapatkan kriteria yang berasal dari perspektif value for money committe. Dari kriteria tersebut dilakukan dekomposisi masalah serta dilakukan tahapan-tahapan AHP (Analytic Hierarchy Proses) untuk mendapatkan bobot dan nilai kontraktor. Metode pembobotan dengan AHP (Analytic Hierarchy Proses) pada penelitian dilakukan dengan memanfaatkan software Expert Choice 11. Expert Choice adalah sebuah perangkat lunak yang khusus dipakai dalam metode AHP, software ini dapat mendukung keputusan yang kompleks dengan membuat keputusan yang lebih efisien, analitis, dan dapat dibenarkan. Data hasil penelitian dimasukan kedalam software expert choice dalam bentuk matriks perbandingan berpasangan, lalu program dijalankan dan dapat dilihat nilai rasio inkonsistensinya. Jika nilai rasio inkonsistensi di atas 10\% atau 0,10 maka harus dilakukan pengambilan data ulang. Hasil perbandingan dalam expert choice ini akan berupa nilai bobot untuk tiap-tiap kriteria dan sub kriteria yang dibandingkan. 
Penilaian dari keseluruhan kriteria yang ditetapkan dalam penilaian proyek. Hasil bobot didapatkan dari matrik pairwise comparation dengan menggunakan bantuan software Expert choice. Dengan bantuan software juga didapatkan nilai consistency $<$ 0,10 (Saaty, 2000, Cheng and Li, 2001) maka nilai matrik tersebut masih konsisten.

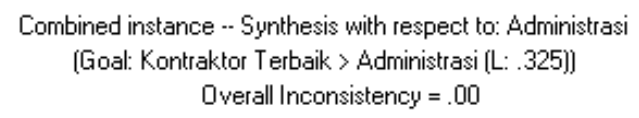

Dokumen Kualifikasi Keuangan Dokumen dari Bank

Daftar Pekerjaan Dalam Pelaksanaan dan fotokopi kontrak Dokumen Kualifikasi Financial TKDN

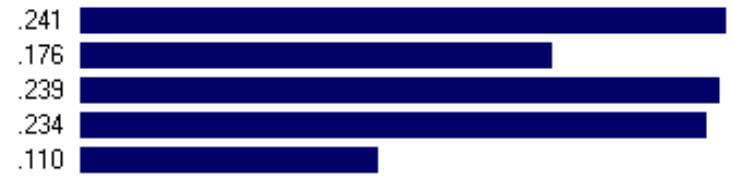

Gambar 3. Pembobotan Sub Kiteria (Kriteria Administrasi)

Combined instance -- Synthesis with respect to: Teknis [Goal: Kontraktor Terbaik > Teknis (L: .375)] Overall Inconsistency $=.00$

Pengalaman produksi pabrikan Surat Keterangan Kepuasan Pelanggan / satisfactory letter Specifikasi Teknis, brosur dan TPG

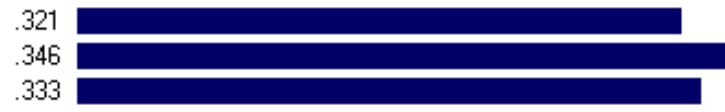

\section{Gambar 4. Pembobotan Sub Kiteria (Kriteria Teknis)}

Combined instance -- Synthesis with respect to: Harga

[Goal: Kontraktor Terbaik > Harga (L: .300)]

Overall Inconsistency $=.00$

$\begin{array}{ll}\text { Penawaran Harga } & .529 \\ \text { Kewajaran Harga } & .471\end{array}$

Gambar 5. Pembobotan Sub Kiteria (Kriteria Harga) 


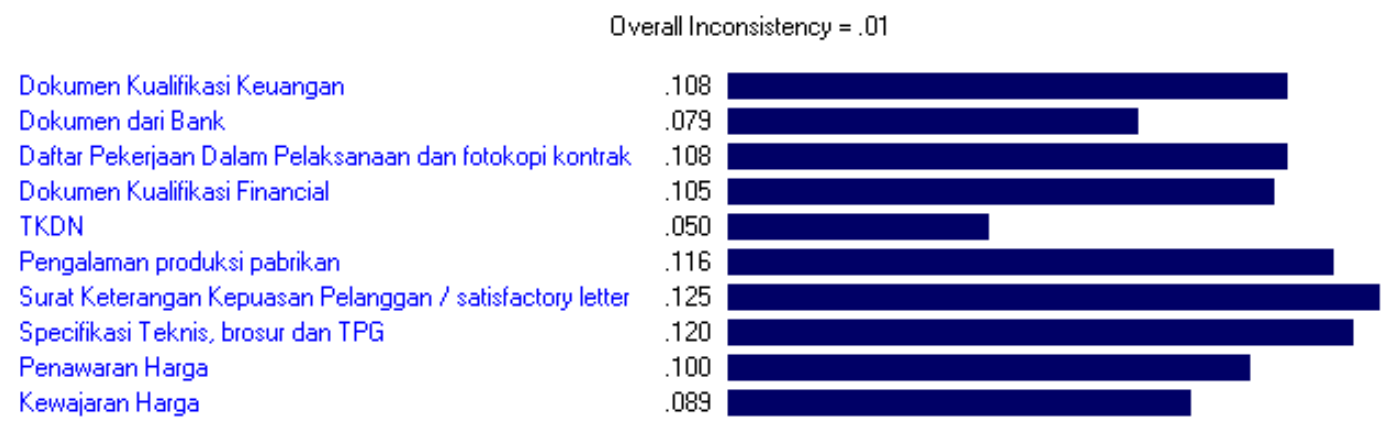

Gambar 6. Pembobotan Sub Kriteria

Hasil penilaian dari keseluruhan sub kriteria didapatkan dari matrik pairwise comparation dengan menggunakan bantuan software Expert choice. Dengan bantuan software juga didapatkan nilai consistency dari matrik tersebut $<0,10$ (Saaty, 2000, Cheng and Li, 2001) maka nilai matrik tersebut masih konsisten.

\section{Perangkingan Alternatif (fuzzy TOPSIS)}

Metode Fuzzy TOPSIS digunakan untuk proses perangkingan alternatif dari setiap kriteria dengan menghitung kedekatan antara solusi dengan setiap alternatif dengan menggunakan bobot kriteria yang telah dihitung menggunakan AHP. Langkah dan Prosedur Metode TOPSIS adalah sebagai berikut :

a. Menentukan Variabel linguistik untuk bobot kriteria, seperti ditunjukkan pada Tabel 3.

Tabel 3. Variabel Linguistik

\begin{tabular}{|c|c|}
\hline Variabel Linguistik & Bilangan Fuzzy \\
\hline Sangat Tinggi & $(0.75,1.00,1.00)$ \\
Tinggi & $(0.50,0.75,1.00)$ \\
Cukup & $(0.25,0.50,0.75)$ \\
Rendah & $(0.00,0.25,0.50)$ \\
Sangat Rendah & $(0.00,0.00,0.25)$ \\
\hline
\end{tabular}

Sumber: data diolah, 2017

b. Membuat Matriks Keputusan Hasil jarak kedekatan antara solusi ideal positif dan negatif ditunjukkan pada Tabel 4. sedangkan matrikss keputusan dari alternatif-alternatif seperti ditunjukkan pada Tabel 5.

Tabel 4. Matrik Keputusan

\begin{tabular}{|c|l|c|c|c|c|c|c|c|c|c|c|}
\hline NO & ALTERNATIF & A8 & A10 & A13 & A15 & A16 & B5 & B6 & B10 & C2 & C3 \\
\hline \hline 1 & PT CA & BK & ST & B & T & RR & A & C & M & A & C \\
\hline 2 & PT PCE & BK & T & D & T & RR & A & C & M & B & C \\
\hline
\end{tabular}

Sumber: data diolah, 2017 
Tabel 5. Matrik Keputusan Fuzzy

\begin{tabular}{|c|c|c|c|c|c|c|c|c|c|c|c|c|}
\hline LTERNA & & A8 & & & A10 & & & A13 & & & A15 & A16 \\
\hline PTCA & 0.75 & 1.00 & 1.00 & 0.75 & 1.00 & 1.00 & 0.50 & 0.75 & 1.00 & 0.50 & \begin{tabular}{|l|l|}
0.75 & 1.00 \\
\end{tabular} & \begin{tabular}{|l|l|l|l|l|l|l|}
0.25 & 0.50 & 0 \\
\end{tabular} \\
\hline PTPCE & 0.75 & 1.00 & 1.00 & 0.50 & 0.75 & 1.00 & 0.00 & 0.25 & 0.50 & 0.50 & \begin{tabular}{|l|l|}
0.75 & 1.00 \\
\end{tabular} & \begin{tabular}{|l|l|l|l|}
0.25 & 0.50 & 0. \\
\end{tabular} \\
\hline LTERNATIF & & B5 & & & B6 & & & $\mathrm{B} 10$ & & & $\mathrm{C} 2$ & $\mathrm{C}$ \\
\hline PTCA & 0.75 & 1.00 & 1.00 & 0.25 & 0.50 & 0.75 & 0.50 & 0.75 & 1.00 & 0.75 & \begin{tabular}{|l|l|}
1.00 & 1.00 \\
\end{tabular} & \begin{tabular}{l|l|l|l|}
0.25 & 0.50 & 0.75 \\
\end{tabular} \\
\hline PTPCE & 0.75 & 1.00 & 1.00 & 0.25 & 0.50 & 0.75 & 0.50 & 0.75 & 1.00 & 0.50 & $0.75|1.00|$ & \begin{tabular}{|l|l|l|l|}
0.25 & 0.50 & 0. \\
\end{tabular} \\
\hline
\end{tabular}

Sumber: data diolah, 2017

Tabel 6. Matrik Keputusan Fuzzy Ternomalisasi Bobot

\begin{tabular}{|c|c|c|c|c|c|c|}
\hline LTERNAT & A8 & $\mathrm{A} 10$ & A13 & & A15 & A16 \\
\hline PTCA & \begin{tabular}{|l|l|l|l|l|}
0.080 & 0.106 & 0.1 \\
\end{tabular} & \begin{tabular}{|l|l|l|}
0.032 & 0.042 & 0.042 \\
\end{tabular} & \begin{tabular}{|l|l|}
0.049 & 0.07 \\
\end{tabular} & & & \\
\hline PTPCE & 0.0800 .10 & \begin{tabular}{|l|l|l|l|l|l|l|l|l|}
0.021 & 0.032 & 0 \\
\end{tabular} & $\begin{array}{lll}0.000 & 0.02 \\
\end{array}$ & & & \begin{tabular}{|l|l|l|l|l|l|l|l|l|l|l|} 
& 0.018 & 0.0 \\
\end{tabular} \\
\hline TERNATIF & $B 5$ & B6 & $\mathrm{B} 10$ & & $\mathrm{C} 2$ & $\mathrm{C3}$ \\
\hline PTCA & \begin{tabular}{|l|l|l|l|}
0.097 & 0.129 & 0.1 \\
\end{tabular} & \begin{tabular}{|l|l|l|l|}
0.032 & 0.065 & 0.097 \\
\end{tabular} & \begin{tabular}{|l|l|l|}
0.065 & 0.09 \\
\end{tabular} & & \begin{tabular}{|l|l|l|l|}
0.088 & 0.117 & 0.117 \\
\end{tabular} & \begin{tabular}{|l|l|l|}
0.029 & 0.059 \\
\end{tabular} \\
\hline PTPCE & \begin{tabular}{|l|l|l|}
0.097 & 0.129 & 0.129 \\
\end{tabular} & \begin{tabular}{|l|l|l|l|}
0.032 & 0.065 & 0.097 \\
\end{tabular} & \begin{tabular}{|l|l|}
0.065 & 0.09 \\
\end{tabular} & \begin{tabular}{|l|l|}
97 & 0.129 \\
\end{tabular} & \begin{tabular}{|l|l|l|l|l|}
0.059 & 0.088 & 0.117 \\
\end{tabular} & \begin{tabular}{|l|l|l|l|l|}
0.029 & 0.059 & 0.08 \\
\end{tabular} \\
\hline
\end{tabular}

Sumber: data diolah, 2017

\section{c. Solusi ideal positif dan solusi ideal negatif}

Hasil penentuan solusi ideal positif dan solusi ideal negatif dengan menggunakan nilai matriks keputusan dapat dilihat di tabel 7. Solusi ideal positif diperoleh dengan memilih nilai terbesar dari tiap kriteria dari seluruh alternatif strategi. Sebaliknya, Solusi ideal positif diperoleh dengan memilih nilai terkecil dari tiap kriteria dari seluruh alternatif strategi.

Tabel 7. Jarak solusi ideal positif dan negatif

\begin{tabular}{|l|c|c|c|}
\hline ALTERNATIF & D* & D- & FC- \\
\hline PT CA & 0.045 & 0.116 & 0.723 \\
\hline PT PCE & 0.046 & 0.114 & 0.714 \\
\hline
\end{tabular}

Sumber: data diolah, 2017

d. Penentuan jarak dengan solusi ideal dan preferensi dari setiap alternatif

Nilai dari matriks keputusan dan solusi ideal digunakan untuk menentukan jarak antara nilai dari setiap alternatif dengan solusi ideal positif dan solusi ideal negatif. Hasil perhitungan jarak dalam bilangan crisp. Alternatif strategi yang dipilih adalah alternatif strategi yang memiliki jarak terpendek dari solusi ideal positif dan jarak terjauh dari solusi ideal negatif.Data kriteria yang diambil pada penelitian ini sebanyak 3 (tiga) item, yaitu: Administrasi, Teknis, dan Waktu serta sub kriteria sebangayk 10 (sepuluh) item yaitu: Dokumen Kualifikasi Keuangan, Dokumen dari Bank, Daftar Pekerjaan Dalam Pelaksanaan, Dokumen Kualifikasi Financial, TKDN, Pengalaman produksi pabrikan, Surat Keterangan Kepuasan Pelanggan, Specifikasi Teknis, brochsure dan TPG, 
Penawaran Harga, dan Kewajaran Penawaran. Sedangkan alternatif sebanyak 2 perusahaan yaitu PT CA dan PT PCE. Data kriteria, sub kriteria dan nilai setiap alternatif tersebut diperoleh dari hasil penilaian yang telah dilakukan oleh Pelaksana Pengadaan PLN UIP ISJ sedangkan nilai perbandingan antar kriteria diperoleh dari hasil wawancara dengan value for money committee standar skala preferensi AHP. Nilai CR yang diperoleh $<0,10$ berarti matriks tersebut konsisten.

Setelah matriks konsisten, maka dapat dilanjutkan ke proses perankingan alternatif dengan metode fuzzy TOPSIS. Nilai preferensi merupakan nilai akhir yang menjadi patokan dalam menentukan peringkat pada semua alternatif yang ada. Hal tersebut berarti semua alternatif akan memiliki nilai preferensi. Nilai preferensi pada suatu alternatif merupakan perbandingan antara jarak terhadap solusi ideal positif dan jarak terhadap solusi ideal negatif, dari hasil perhitungan nilai preferensi alternatif yang paling besar adalah alternatif PT CA, yaitu sebesar 0,723 sehingga disimpulkan bahwa Alternatif PT CA direkomendasikan untuk menjadi pemenang lelang/kontraktor terbaik.

\section{Kesimpulan}

Berdasarkan hasil penelitian, pembahasan dan intepretasi data yang telah diuraikan dengan mengacu pada beberapa teori dan hasil penelitian sebelumnya, maka hasil penelitian ini dapat disimpulkan bahwa penerapan metode AHP dan Fuzzy TOPSIS dalam pemilihan kontraktor ini dapat dapat memberikan rekomendasi alternatif untuk pengambil keputusan, sehingga proses pemilihan kontraktor dapat berlangsung secara efektif dan efisien serta menghasilkan keputusan yang lebih konsisten. Hasil Implementasi penelitian untuk pemilihan kontraktor dengan 10 kriteria penilaian diperoleh hasil pembobotan kriteria dengan menggunakan metode AHP. Dari hasil pembobotan tersebut kemudian dilanjutkan proses perangkingan alternatif dengan menggunakan metode Fuzzy TOPSIS diperoleh hasil preferensi yang terbaik dan terpilih PT CA adalah sebesar 0,723.

\section{Saran}

Adapun saran yang diberikan untuk penelitian ini adalah sebagai berikut : (1) Penulis menyampaikan masukan kepada Manajemen PT. PLN (Persero) UIP ISJ agar pelaksanakan pengadaan barang/jasa dilakukan pembobotan dan disampaikan kepada calon penyedia barang/jasa; (2) Diharapkan PT PLN (Persero) UIP ISJ menyampaikan ke PT PLN (Persero) Kantror Pusat untuk mempertimbangkan metode ini dan dibuatkan edaran sebagai dasar pengadaan barang/jasa di lingkungan PT PLN (Persero); (3) Penelitian selanjutnya 
dapat membandingkan beberapa metode MCDM yang lain dalam menentukan prioritas penilaian kontraktor. Serta melakukan perbandingan dengan menggunakan beberapa alternatif penilaian agar diketahui metode mana yang paling baik; (4) Data untuk metode AHP (Analytic Hierarchy Process) dalam studi ini mengandalkan penilaian responden terhadap faktor-faktor yang diajukan. Karena penilaian akan sangat bervariasi antar satu dengan yang lainnya (sebagaimana ditunjukan dalam distribusi frekuensi data), maka penambahan jumlah responden dengan sumber yang semakin luas melibatkan para ahli perlu dilakukan guna menjaga konsistensi data.

\section{Daftar Referensi}

Calabrese, A, Costa R and Menichini, T., 2013. Using fuzzy AHP to manage intellectual capital assets : an application to the ICT service industry, Expert Systems with Applications $x x x, x x x-x x x$

Liauwnoto, Suparto. 2009. Model pemilihan kontraktor pemenang tender di sektor swasta menggunakan analytical hierarchi process. Master thesis, Petra Christian University.

Peraturan Direksi PT PLN (Persero) Nomor : 0527.K/DIR/2014 Tanggal 31 Oktober 2014 tentang Perubahan atas Keputusan Direksi PT PLN (Persero) Nomor 0620.K/DIR/2013 tentang Pedoman Umum Pengadaan Barang/Jasa PT PLN (Persero).

Peraturan Menteri Badan Usaha Milik Negara Nomor PER-15/MBU/2012 tentang Perubahan Atas Peraturan Menteri Negara Badan Usaha Milik Negara Nomor PER-05/MBU/2008 tentang Pedoman Umum Pelaksanaan Pengadaan Barang dan Jasa Badan Usaha Milik Negara.

Rouhani, S., Ghazanfari, M. and Jafari, M. 2012. Evaluation model of business intelligence for enterprise systems using fuzzy TOPSIS, Expert Systems with Applications, 3764-3771

Saaty, T. L., (2000). Decision making with the analitic hierarchy process. Int.J.Services Sciences, Vol.1, No. 1, pp.83-98

Tantyonimpuno, R. S \& Retnaningtias , A. D. 2006. "Penerapan Metode Analytical Hierarchy Process (Ahp) Pada Proses Pengambilan Keputusan Pemilihan Jenis Pondasi (Studi Kasus : Proyek Pembangunan Royal Plaza Surabaya)

Watt, D.J., Kayis, B., Willey, K. 2010. The Relative importance of Tender Evaluation and Contractor Selection Kriteria. International Journal Of Project Management, 28 (1), 51-60

Wong, C.H., Holt, G.D. and Cooper, P.A. 2000. Lowest price or value? Investigation of UK construction clients' tender selection process. Construction Management andEconomics. 18, 767-74. 